\title{
Anti-inflammatory effect of Pyrrosia lingua extract on Raw 264.7 macrophages
}

\author{
Shin Hyub Hong ${ }^{1 \neq}$, Eun-Ho Lee ${ }^{1 \neq}$, Hye-Jin Park ${ }^{1}$, Jung In Kim ${ }^{1}$, Hee-Young Jung ${ }^{2}$, \\ In-Kyu Kang ${ }^{3}$, Byung-Oh Kim ${ }^{1}$, Heui-Dong Park ${ }^{1}$, Young-Je Cho ${ }^{1 *}$ \\ ${ }^{1}$ School of Food Science \& Biotechnology, Kyungpook National University, Daegu 41566, Korea \\ ${ }^{2}$ School of Applied Biosciences, Kyungpook National University, Daegu 41566, Korea \\ ${ }^{3}$ Department of Horticultural Science, Kyungpook National University, Daegu 41566, Korea
}

\section{Raw 264.7 macrophages에 대한 Pyrrosia lingua 추출물의 항염증 효과

\author{
홍신협 $^{1 \neq} \cdot$ 이은호 ${ }^{1 \neq} \cdot$ 박혜진 $^{1} \cdot$ 김정인 $^{1} \cdot$ 정희영 $^{2} \cdot$ 강인규 $^{3} \cdot$ 김병오 $^{1} \cdot$ 박희동 $^{1} \cdot$ 조영제 $^{1 *}$ \\ 1경북대학교 식품공학부, ${ }^{2}$ 경북대학교 응용생명과학부, ${ }^{3}$ 경북대학교 원예과학과
}

\begin{abstract}
To test the potential use of the fern Pyrrosia lingua as an anti-inflammatory functional material, we examined the effects of $P$. lingua ethanol extract (PLE) on RAW 264.7 macrophages treated with the pro-inflammatory molecule lipopolysaccharide (LPS). Notably, up to $100 \mu \mathrm{g} / \mathrm{mL}$ PLE did not result in any discemable inhibition of cellular metabolic activity or cytotoxicity in the macrophages. However, supplementing LPS-treated RAW 264.7 macrophages with PLE significantly suppressed various pro-inflammatory responses in a dose-dependent manner, including i) phosphorylation of nuclear factor-kappa $B$ (NF-kB) subunit p65; ii) accumulation of inducible nitric oxide synthase and cyclooxygenase-2; iii) expression of pro-inflammatory mediators, including prostaglandin $\mathbf{E}$ synthase 2 and nitrite; and iv) expression of pro-inflammatory biomarker genes, including interleukin 1 beta, interleukin 6, tumor necrosis factor-alpha, and monocyte chemoattractant protein-1. Taken together, our results indicate that PLE regulates NF-KB signaling and inhibits cytokine production. Therefore, the use of domestic biological resources like could be increased $P$. lingua as a novel functional material.
\end{abstract}

Keywords : anti-inflammation, biomarker genes, lipopolysaccharide, macrophage, Pyrrosia lingua

서 론

염증반응은 다양한 세포에서 분비되는 산화적 스트레스 물질이나 감염성 물질에 의하여 유발되는 정상적인 방어기전 으로써 한시적으로 일어나고 빠르게 회복된다(Kim 등, 2000). 그렇지만 다양한 염증성 질환들에서 염증반응과 면역이 적절 하게 감소되지 않고, 염증성 면역세포에 분비되는 ROS, 과도
한 염증성 cytokine 및 chemokine이 대장 및 지방을 포함하 여서 여러 조직에 만성적인 염증반응을 일으키는 것으로 알 려져 있다(Mases, 2008). Chemokine 중에서도 monocyte chemoattractant protein 1(MCP-1)은 CC chemokine으로써 단 핵구, 림프구, 호염구 등을 선택적으로 유도하며, interleukin-1 $\beta$ (IL-1 $\beta)$, tumor necrosis factor- $\alpha(\mathrm{TNF}-\alpha)$, 저밀도 지단백질 $(\mathrm{LDL})$ 등에 반응하여 기질세포, 사구체의 내피, 세뇨관 상피

\footnotetext{
*Corresponding author. E-mail : yjcho@knu.ac.kr, Phone : +82-53-950-7755, Fax : +82-53-950-7762

${ }^{\ddagger}$ These authors contributed equally to this work.

Received 17 June 2021; Revised 23 July 2021; Accepted 28 July 2021.

Copyright (c) The Korean Society of Food Preservation.

This is an Open Access article distributed under the terms of the Creative Commons Attribution Non-Commercial License (http://creativecommons.org/licenses/by-nc/4.0) which permits unrestricted non-commercial use, distribution, and reproduction in any medium, provided the original work is properly cited.
} 
세포, 모세혈관의 내피세포 및 평활근세포 등에서 생산된다 고 보고되고 있다(Kim 등, 2002). Nuclear factor-kappa B (NF-kB)는 염증 반응, 세포 증식, 면역 및 세포 사멸과 관련된 유전자의 신호전달 및 발현에 관여하는 유도성 전사인자이며 (Park과 Hong, 2016), NF-kB 경로는 TNF receptor superfamily members(TNFRs), T-cell receptor(TCR), B-cell receptor(BCR) 와 TNF- $\alpha$, interleukin- $1 \beta(\mathrm{IL}-1 \beta)$ 와 같은 염증성 cytokine에 의해 유발된다(Barroso 등, 2016). NF-kB family transcription factor complexes는 p50, p52, p65(ReIA), ReIB 및 c-Rel과 같은 NF-kB 단위 구성원에 의해 형성된 동종 또는 이종이량 체로 구성되어 있으며, 핵 내로 이동하여 TNF- $\alpha$, IL- $6, \mathrm{IL}-8$, $\mathrm{IL}-1 \beta$ 및 MCP-1와 같은 염증 반응에 관여하는 다기능 cytokine 의 전사를 조절한다. 또한 arachidonic acid를 prostaglandin $\mathrm{E}_{2}$ $\left(\mathrm{PGE}_{2}\right)$ 로 전환시켜 피부 염증을 유발하는 염증 효소인 cyclooxygenase-2(COX-2)의 발현과 염증 매개체인 NO와 $\mathrm{NO}$ 를 합성하는 inducible nitric oxide synthase(iNOS)의 발 현을 유도한다. iNOS 과발현은 만성 염증, 인간 종양의 발생 및 발암과도 관련이 있다(Kuo 등, 2015; Lindstrom과 Bennett, 2005). 그 중에 nitric oxide(NO)는 여러 염증 반응에 핵심적 인 매개 물질이다(Lee 등, 2008). NO는 혈류와 혈압을 조절, 혈소판의 응집을 억제, 신경전달과정 등에 관여하여 인체의 방어기전과 면역조절로서 중요한 역할을 하고, 염증상태에서 과도하게 $\mathrm{NO}$ 가 생성되면 부종, 혈관투과성 등 염증반응이 촉진되며, 염증 매개체의 생합성이 촉진되어 급성 또는 만성 염증에 대한 반응이 나타나 조직 손상 및 유전자 변이 등이 나타날 수 있다(Ryu 등, 2003). $\mathrm{PGE}_{2}$ 의 합성은 phospholipase $\mathrm{A} 2$ 의 효소작용에 의해 막 인지질(membrane phospholipid)로부 터 arachidonic acid가 만들어지는 것으로 시작된다. Arachidonic acid는 효소작용에 의해 $\mathrm{PGG}_{2}$ 가 되고, 다시 불안정한 대사산 물인 $\mathrm{PGH}_{2}$ 가 되는데, 이 두 과정은 $\mathrm{COX}$ 에 의해 촉진된다 $(\mathrm{Ji}$ 등, 2004). Eicosanoinds의 생합성 과정 중에서 $\mathrm{COX}$ 에 의해 염증 반응이 진행되며, 유효성 효소들과 염증성은 $\mathrm{COX}-2$ 에 의해 나타난다(Gordon, 1998). 염증반응에 중요 역할을 하는 $\mathrm{PGE}_{2}$ 는 COX-2에 의하여 형성되며, 염증 반응의 매개체로서 의 역할뿐만 아니라(Bishop 등, 2002), Th2 type 면역반응을 촉진하고 Th1 type의 면역반응은 억제하며, 대식세포에서 TNF- $\alpha$, IL- $1 \beta$, IL- 8, IL-12 등의 pro-inflammatory의 생성을 억제하고, 항염증성 cytokine의 생성을 촉진하는 면역반응의 조절자로서의 역할이 최근 수년간의 연구에서 밝혀진 바 있 다(Harris 등, 2002).

석위(Pyrrosia lingua)는 상록성 양치식물로서 고란초과 (Polypodiaceae)에 속한다. 우리나라 남부지방, 제주도 등 따 뜻한 지역의 산지 바위나 나무껍질에 분포하여 자생하는 여 러해살이풀이다(Do 등, 1992; Yamashita 등, 1998). 한방에 서는 지상부의 전초를 말려 통증, 요로결석 형성 및 질 출혈에
유용한 효과가 있는 한약재로 사용되고 있다. 이 식물에 대한 이전의 식물 화학적 연구에서 chlorogenic acid, xanthonoids, kaempferol, isoorientin, organic acids, xanthones, triterpenoids, steroids 및 volatile oil 등이 조사되어 알려져 있으며(Chen 등, 2011), 항바이러스, 정균, 이뇨제, 면역강화 및 신장보호 활성 등의 많은 기능성 효과를 가지고 있다고 보고된 바 있다 (Kim 등, 2010; Lim 등, 2014). 그러나 이러한 석위가 약리적 효능을 보유하고 있을 가능성에도 불구하고, 현재까지는 석위 의 항산화 및 진통 효능 등만 보고되고 있으며(Kim 등, 2017), 아직까지 석위의 염증 억제에 관한 과학적 연구가 이뤄지지 않았고, 그를 밝히기 위한 수행 연구가 필요한 실정이다.

본 연구에서는 Raw 264.7 cell에서 NF-kB 신호 전달 조절 을 통해 cytokine의 발현량을 조절하기 위해 Pyrrosia lingua ethanol extract(PLE)를 처리하여 NF- $\mathrm{NB}$ p-65, iNOS, COX-2 단백질을 확인한 후, 이들의 pro-inflammatory mediators인 prostaglandin E synthase 2(PTGES2)와 nitrite의 발현량, cytokine 발현 수준을 통해 염증 억제 연구를 수행하였다.

\section{재료 및 방법}

\section{측정 시약 및 기기}

실험에 사용한 세포는 mouse 유래의 macrophage인 Raw 264.7 cell(Korean Cell Line Research Foundation)을 구매하 여 사용하였다. 사용한 시약은 Dulbecco's modified Eagle's medium(DMEM)(HyClone Laboratories, Inc., Logan, Utah, USA), inactivated fetal bovine serum(FBS)(HyClone Laboratories, Inc.), penicillin-streptomycin(HyClone Laboratories, Inc.), dimethyl sulfoxide(DMSO)(Junsei Chemical Co., Tokyo, Japan), 3-(4,5-dimethylthiazol-2-yl)-2,5-diphenyltetrazolium bromide (MTT)(Sigma-Aldrich Co., Louis, MO, USA), phosphate buffer saline(PBS)(HyClone Laboratories, Inc.), mammalian protein extraction reagent(M-PER)(Thermo Fisher Scientific, Waltham, MA, USA), nuclear and cytoplasmic extraction reagents(NE-PER)(Thermo Fisher Scientific.), protease inhibitor (Thermo Fisher Scientific.), BCA kit(Thermo Fisher Scientific.), polyvinylidene fluoride(PVDF) membrane(Millipore Corp, Bedford, MA, USA) 등의 시약을 구입하여 사용하였다.

Western blot을 측정하기 위한 시약은 $\operatorname{iNOS}(1: 1,000$ in 5\% skim milk; \#sc-7271; Santa Cruz Biotechnology, Dallas, TX, USA), COX-2(1:500 in 5\% skim milk; \#33345; Signalway antibody, Maryland, College Park, USA), NF-кB p65(1:1,000 in 5\% skim milk; \#6956T; Cell Signaling Technology, Danvers, MA, USA), p-NF-KB p65(1:500 in 5\% skim milk; \#3036S; Cell Signaling Technology), glyceraldehyde 3phosphate dehydrogenase(GAPDH)(1:1,000 in 5\% skim milk; 
\#MA5-15738; Thermo Fisher Scientific.), $\beta$-actin(1:500 in $5 \%$ skim milk or 5\% BSA; \#sc-47778; Santa Cruz Biotechnology) antibody와 mouse anti-rabbit $\operatorname{lgG}-\mathrm{HRP}(1: 1,000$; sc-2357; Santa Cruz Biotechnology), goat anti- mouse $\operatorname{IgG}(1: 1,000$; 31430; Thermo Fisher Scientific.) secondary antibody를 구 입하여 사용하였다.

Real-time polymerase chain reaction(PCR)을 측정하기 위 한 시약은 GeneAll ${ }^{\circledR}$ Ribospin RNA extraction kit(GeneAll Biotechnology Co, Seoul, Korea), qPCRBIO cDNA synthesis kit(PCR Biosystems, London, UK), Real time PCR master mix $5 \mu \mathrm{L}$ (GeneAll Biotechnology Co.)를 구입하여 사용하였 다.

본 실험에 사용된 기기는 동결건조기(freeze dryer, FD8518, Ilshinbiobase, Yangju, Korea), rotary vacuum evaporator (Eyela NE, Tokyo, Japan), $\mathrm{CO}_{2}$ incubator(311, Thermo Fisher Scientific.), heating block(MaXtable H10-Set, Daihan scientific co., Ltd., Wonju, Korea), enzyme-linked immunosorbent assay(ELISA) reader(SPECTRO star Nano, BMG LABTECH, Ortenberg, Germany), transfer cell 기기(Hofer, Holliston, MA, USA), Azure Biosystems(C300, Azure Biosystems inc., Dublin, CA, USA), PCRmax Eco 48 real-time PCR system (PCRmax, Staffordshire, UK) 등을 사용하였다.

\section{시험 재료 및 추출물의 제조}

본 연구에서 사용된 Pyrrosia lingua는 서울약령시장 (주)천 지가약초(Seoul, Korea)에서 2017년에 구입하여 사용하였다. 재료로 사용된 Pyrrosia lingua 잎은 이물질을 제거한 후, $45^{\circ} \mathrm{C}$ dry oven(Jeiotech, Daegu, Korea)에서 건조한 후, 고속분쇄 기(RT-08, Rong Tsong Precision Technology, Taichung, Taiwan)를 이용하여 25,000 rpm으로 분쇄하여 40 mesh 채 에 걸러 powder 형태로 제조한 다음 $4^{\circ} \mathrm{C}$ 에서 저온저장하며 사용하였다. 실험에 사용한 추출물은 Pyrrosia lingua 잎 분 말에 $80 \%$ ethanol 용액(1:100)을 첨가하여 24시간 동안 shaking incubator에서 실온으로 교반 추출하였다. 추출물은 filter paper(No.1, Whatman Inc., Piscataway, New Jersey, USA)로 여과한 후 rotary vacuum evaporator를 이용하여 농 축하여 유기용매를 제거하였다. 농축된 추출물은 동결건조 한 후 $\mathrm{DMSO}$ 에 용해하여 $-20^{\circ} \mathrm{C}$ 시료 보관 냉장고에서 저온 보관하며 실험에 사용하였다.

\section{세포 배양}

Mouse 유래의 macrophage인 Raw 264.7 cell을 10\% FBS 와 $1 \%$ penicillin-streptomycin을 첨가한 DMEM 배지를 이용 하여 $37^{\circ} \mathrm{C}$ 의 $5 \% \mathrm{CO}_{2}$ incubator를 이용하여 배양하였다.

\section{세포독성 측정}

Pyrrosia lingua ethanol extract(PLE)가 세포에 독성을 일 으키는지 평가하기 위해 MTT assay로 확인하였다. Raw 264.7 cell $\left(5 \times 10^{3}\right.$ cells $\left./ \mathrm{mL}\right)$ 을 각각 48 well plate에 분주하여 24시간 전 배양한 후, PLE를 5-100 $\mu \mathrm{g} / \mathrm{mL}$ 농도별로 첨가한 배양액을 처리하고 18 시간 배양하였다. 이후 well plate에 5 $\mathrm{mg} / \mathrm{mL} \mathrm{MTT}$ 시약 $50 \mu \mathrm{L}$ 를 첨가하여 4시간 동안 반응시키 고 배양액을 제거한 후, 남아있는 formazan을 DMSO로 용해 시켜 ELISA reader를 이용해 $540 \mathrm{~nm}$ 에서 흡광도를 측정하 였다. 시료의 독성이 정상상태의 Raw 264.7 cell에 영향을 미 치는지 확인하기 위해 세포의 수와 형태학적 변화를 현미경 $(\times 400$, ECLIPSE TS100, Nikon, Tokyo, Japan)으로 관찰하 였다.

\section{Nitrite 분석}

Lipopolysaccharide(LPS)로 자극된 세포로부터 생성된 nitrite 에 대한 PLE가 미치는 영향을 알아보기 위해 griess reagent system's kit 시약( $1 \%$ sulfanilamide $+0.1 \%$ naphthylendiamine dihydrochloride, 1:1) 반응을 이용하여 배양액 중에 존재하는 $\mathrm{NO}_{2}{ }^{-}$의 형태로 측정하였다. Raw $264.7 \operatorname{cell}\left(5 \times 10^{4}\right.$ cells $\left./ \mathrm{mL}\right)$ 을 96 well plate에 분주하고, $37^{\circ} \mathrm{C}$ 의 $5 \% \mathrm{CO}_{2}$ incubator에서 24시간 전 배양하였다. 세포에 $1 \mu \mathrm{g} / \mathrm{mL}$ 의 LPS와 PLE를 농도 별로 처리한 배양액으로 18 시간 재배양하였다. Nitrite 생성량 은 supernatant를 모아 griess reagent system's kit를 사용하여 반응시킨 후 ELISA reader를 이용하여 $540 \mathrm{~nm}$ 에서 흡광도를 측정하였다. 세포 배양액 내 nitrite의 농도는 $0.1 \mathrm{M}$ sodium nitrite $\left(\mathrm{NaNO}_{2}\right)$ 의 농도별 표준곡선에 대입하여 산출하였다.

\section{Western blot을 이용한 protein 발현량 측정}

LPS로 자극된 Raw 264.7 cell $\left(5 \times 10^{5}\right.$ cells $\left./ \mathrm{mL}\right)$ 의 COX-2, iNOS protein 발현량 측정을 위해 6 well plate에 세포를 분 주하고, 24시간 전 배양하여 세포에 $1 \mu \mathrm{g} / \mathrm{mL} \mathrm{LPS}$ 로 자극을 준 다음, PLE를 농도별 $(20-50 \mu \mathrm{g} / \mathrm{mL})$ 로 처리한 배양액으로 24시간 재배양하고 PBS로 3회 세척하였다. M-PER와 protease inhibitor를 섞은 mixture를 각 well당 $70 \mu \mathrm{L}$ 첨가하여 $4^{\circ} \mathrm{C}$ 에 서 lysis시킨 후, $16,000 \times g$ 에서 20 분간 저온 원심 분리기 ( $4^{\circ} \mathrm{C}$, Gyrozen, Seoul, Korea)를 이용하여 세포막 성분 등을 제거하였다. 원심 분리하여 얻은 supernatant는 $\mathrm{BCA}$ kit로 정 량하였으며, 총 20-30 $\mu \mathrm{g}$ 의 단백질을 $10 \%$ 의 sodium dodecyl sulfate-polyacrylamide gel electrophoresis(SDS-PAGE)를 통 해 $100 \mathrm{~V}$ 로 1 시간 30 분간 전기 영동하여 분리하였다. 분리된 단백질은 transfer cell 기기를 이용하여 $60 \mathrm{~V}$ 로 2시간 30 분 간 PVDF membrane으로 transfer한 후 실온에서 1시간 동안 blocking하였다. Blocking이 끝난 membrane에 COX-2, iNOS, 
GAPDH antibody를 사용하여 $4^{\circ} \mathrm{C}$ 에서 over night한 후, buffer를 이용하여 3회 세척하였다. Goat anti-mouse $\operatorname{IgG}$ secondary antibody를 1시간 동안 반응시킨 후 $1 \times \mathrm{TBST}$ buffer로 3회 세척하였으며, enhanced chemiluminescence (ECL) kit(Millipore Corp.)와 반응시켜 Azure Biosystems를 이용하여 band를 현상하고, Image J software(NIH-Scion, USA)를 사용하여 정량하였다.

\section{Cytoplasmic과 nuclear 분획}

LPS로 자극된 Raw 264.7 cell $\left(2 \times 10^{6}\right.$ cells $\left./ \mathrm{mL}\right)$ 이 되도록 분주하고, $5 \% \mathrm{CO}_{2}$ incubator에서 $37^{\circ} \mathrm{C}$ 로 24 시간 동안 배양 하였다. 교체된 배지에 LPS $(1 \mu \mathrm{g} / \mathrm{mL})$ 로 자극을 준 다음 PLE 를 농도별로 첨가한 배양액을 처리하고 30-60분 동안 배양하 였다. 배양 후, 세포를 수집하고 차가운 PBS로 3 회 세척하였 다. Cytoplasmic과 nuclear 단백질 추출은 제조업체의 프로토
콜에 따라 NE-PER를 사용하여 준비하였다.

\section{Real-time PCR을 이용한 $\mathrm{mRNA}$ 발현량 측정}

LPS로 자극된 Raw 264.7 cell $\left(5 \times 10^{6}\right.$ cells $\left./ \mathrm{mL}\right)$ 의 TNF- $\alpha$, IL-1 $\beta$, IL-6, MCP-1, prostaglandin E synthase 2(PTGES2) mRNA 발현량 측정은 $100 \times 20 \mathrm{~mm}$ culture dish에 세포를 분 주하고 24시간 전 배양하여 $1 \mu \mathrm{g} / \mathrm{mL}$ 의 LPS를 처리하고 PLE 를 농도별로 처리한 배양액으로 24 시간 재배양하고 $\mathrm{PBS}$ 로 3 회 세척하였다. mRNA 발현량을 비교 분석하기 위해 제조업 체의 프로토콜에 따라 total RNA를 GeneAll ${ }^{\circledR}$ Ribospin RNA extraction kit를 사용하여 추출하였으며, $\mathrm{qPCRBIO} \mathrm{cDNA}$ synthesis Kit를 이용하여 $\mathrm{cDNA}$ 를 합성하였다. 합성된 cDNA 는 PCRmax Eco 48 real-time PCR system을 이용하여 유전 자별로 mRNA 발현량을 실시간 분석하였으며, PCR condition 과 primer sequence는 Table 1,2 와 같다.

Table 1. The primer sequences of real-time PCR

\begin{tabular}{|c|c|c|c|c|}
\hline Gene & Accession & primer & Sequence $\left(5^{\prime}-3^{\prime}\right)$ & Amplicon (bp) \\
\hline \multirow{2}{*}{ TNF- $\alpha$} & \multirow{2}{*}{ NM_001278601.1 } & Forward & TCTACTGAACTTCGGGGTGA & \multirow{2}{*}{87} \\
\hline & & Reverse & AGGGTCTGGGCCATAGAACT & \\
\hline \multirow{2}{*}{ IL-1 $\beta$} & \multirow{2}{*}{ NM_008361.4 } & Forward & CAACCAACAAGTGATATTCTCCATG & \multirow{2}{*}{152} \\
\hline & & Reverse & GATCCACACTCTCCAGCTGCA & \\
\hline \multirow{2}{*}{ IL-6 } & \multirow{2}{*}{ NM_031168.2 } & Forward & TAGTCCTTCCTACCCCAATTTCC & \multirow{2}{*}{76} \\
\hline & & Reverse & TTGGTCCTTAGCCACTCCTTC & \\
\hline \multirow{2}{*}{ MCP-1 } & \multirow{2}{*}{ NM_011333.3 } & Forward & TTCСТCCACCACCATGCAG & \multirow{2}{*}{64} \\
\hline & & Reverse & CCAGCCGGCAACTGTGA & \\
\hline \multirow{2}{*}{ PTGES2 } & \multirow{2}{*}{ NM_133783.2 } & Forward & CCGTGAGAAGGACTGAGATC & \multirow{2}{*}{162} \\
\hline & & Reverse & AAGTGATGACCTCTTCCAGG & \\
\hline \multirow{2}{*}{ GAPDH } & \multirow{2}{*}{ NM_008084.3 } & Forward & TGCACCACCAACTGCTTAGC & \multirow{2}{*}{87} \\
\hline & & Reverse & GGCATGGACTGTGGTCATGAG & \\
\hline \multirow{2}{*}{$\beta$-Actin } & \multirow{2}{*}{ NM_007393.4 } & Forward & CGTGCGTGACATCAAAGAGAA & \multirow{2}{*}{137} \\
\hline & & Reverse & GCTCGTTGCCAATAGTGATGA & \\
\hline
\end{tabular}

Table 2. Real-time PCR conditions

\begin{tabular}{cl}
\hline Gene & \multicolumn{1}{c}{ Real-time PCR condition } \\
\hline $\begin{array}{c}\text { TNF- } \alpha, \text { IL-1 } \beta, \text { MCP-1, } \\
\text { PTGES2, GAPDH }\end{array}$ & $\begin{array}{l}95^{\circ} \mathrm{C} \text { for } 5 \mathrm{~min}, \text { followed by undergoing } 40 \text { cycles of } 95^{\circ} \mathrm{C} \text { for } 10 \mathrm{~s}, 60^{\circ} \mathrm{C} \text { for } 20 \mathrm{~s} \text {, followed by each } 95^{\circ} \mathrm{C}, \\
60^{\circ} \mathrm{C}, 95^{\circ} \mathrm{C} \text { for } 15 \mathrm{~s}\end{array}$ \\
\hline IL-6 & $\begin{array}{c}95^{\circ} \mathrm{C} \text { for } 5 \mathrm{~min}, \text { followed by undergoing } 40 \text { cycles of } 95^{\circ} \mathrm{C} \text { for } 10 \mathrm{~s}, 60^{\circ} \mathrm{C} \text { for } 20 \mathrm{~s}, 72^{\circ} \mathrm{C} \text { for } 15 \mathrm{~s}, \text { followed } \\
\text { by each } 95^{\circ} \mathrm{C}, 60^{\circ} \mathrm{C}, 95^{\circ} \mathrm{C} \text { for } 15 \mathrm{~s}\end{array}$ \\
\hline$\beta$-Actin & $\begin{array}{l}95^{\circ} \mathrm{C} \text { for } 5 \text { min, followed by undergoing } 40 \text { cycles of } 95^{\circ} \mathrm{C} \text { for } 10 \mathrm{~s}, 60^{\circ} \mathrm{C} \text { for } 20 \mathrm{~s} \text { or } 95^{\circ} \mathrm{C} \text { for } 10 \mathrm{~s}, 60^{\circ} \mathrm{C} \\
\text { for } 20 \mathrm{~s}, 72^{\circ} \mathrm{C} \text { for } 15 \mathrm{~s} \text {, followed by each } 95^{\circ} \mathrm{C}, 60^{\circ} \mathrm{C}, 95^{\circ} \mathrm{C} \text { for } 15 \mathrm{~s}\end{array}$ \\
\hline
\end{tabular}




\section{통계처리}

모든 실험은 3 회 이상 반복 측정하였고, 자료의 통계처리 는 IBM SPSS statistics 26 for windows(Statistical Package for Social Science, Chicago, IL, USA)를 이용하여 평균 \pm 표 준편차(mean \pm standard deviation)로 표시하였고, 유의적인 차 이를 검증하기 위해 일원배치분산분석(one-way ANOVA), Duncan's multiple range test를 실시하여 시료간의 유의차를 $\mathrm{p}<0.05$ 또는 $\mathrm{p}<0.01$ 수준으로 비교 분석하였다.

\section{결과 및 고찰}

\section{Raw 264.7 cell에 대한 PLE의 세포독성}

PLE의 Raw 264.7 cell에 대한 독성을 확인하기 위해 MTT assay를 이용하여 세포 생존율을 측정한 결과는 Fig. 1(A)와 같다. 정상상태의 Raw 264.7 cell에 PLE를 5, 10, 20, 30, 50, $100 \mu \mathrm{g} / \mathrm{mL}$ 의 농도별로 처리하였을 때 PLE 처리군에서는 농 도가 증가하여도 세포 생존율이 유의적으로 감소하는 경향이 나타나지 않았으며, $100 \mu \mathrm{g} / \mathrm{mL}$ 의 고농도로 처리하였을 때도 세포 생존율이 $97.7 \%$ 로 확인되어 고농도의 PLE 처리 시에

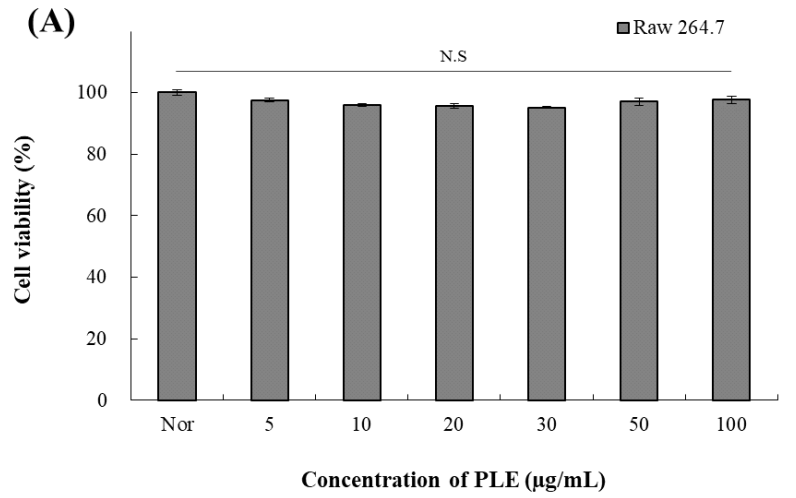

도 시료가 세포에 독성을 나타내지 않는 것으로 확인되었다. 이러한 결과를 확인하기 위해 시료를 처리한 후 $0,12,24$ 시 간 후에 현미경을 통해서 세포의 수를 세고(Fig. 1(B)), 형태 학적 변화도 관찰하였다(Fig. 1(C)). 그 결과는 Fig. 1(A)에서 와 같이 PLE 처리군에서 MTT assay에서 나타난 세포독성의 경향과 유사한 결과를 나타내었다 $(\mathrm{p}<0.01)$. 위의 결과에 따 라 PLE는 Raw 264.7 cell에 대한 세포독성을 가지지 않음을 확인하여 $100 \mu \mathrm{g} / \mathrm{mL}$ 를 최고 농도로 설정하여 추후 실험에 적용하였다.

\section{PLE가 LPS 유도된 Raw 264.7 cell에서 NF- $\kappa$ B 신호 경로 에 미치는 영향}

면역반응의 일종인 염증은 외부 자극, 병원체 또는 손상된 조직의 침입에 대한 방어적 보호 메커니즘이다(Oh 등, 2013). 외부 자극에 의한 염증은 주로 NF-kB 신호전달경로에 의해 조절된다. NF- $\mathrm{kB}$ 는 면역체계 조절(immune modulation), 상 피세포의 분화(epithelial differentiation) 및 염증반응 조절 등 에 관여하는 단백질군(protein family)으로 유전자의 발현을 조절하여 세포 내 신호전달 체계를 이루는 인자이다(Shin 등,

(C)

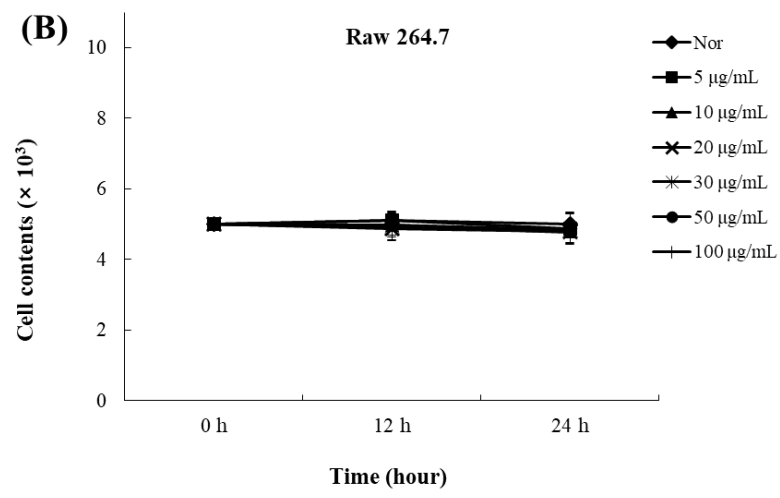

PLE $(\mu \mathrm{g} / \mathrm{mL})$

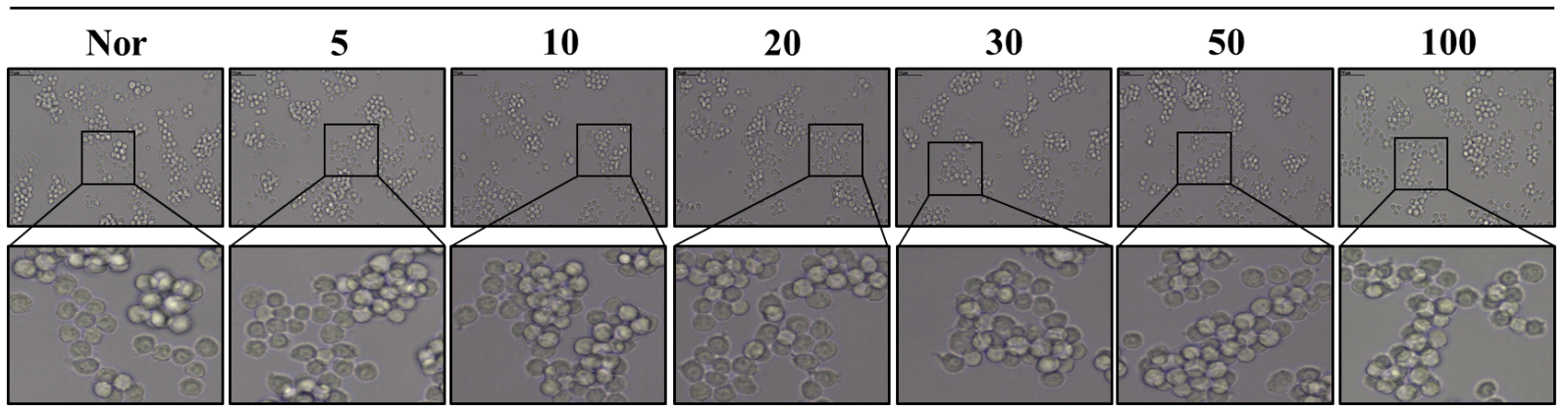

Fig. 1. Cell cytotoxicity of PLE (5-100 $\mu \mathrm{g} / \mathrm{mL})$ on Raw 264.7 cell.

A, The cell viability was assessed using an MTT reduction assay. B, Cell numbers were counted in the cell culture plates after incubation with PLE for 0,12 , and $24 \mathrm{~h}$. C, Cell morphological changes were monitored by inverted phase-contrast microscopy (magnification, $\times 400$ ). The values are mean $\pm \mathrm{SD}$ of three independent experiments $(\mathrm{p}<0.01)$. Nor, negative control group; NS, not significant. 
2012). 비활성 상태의 NF- $\kappa \mathrm{B}$ 복합체는 세포질에서 $\mathrm{I} \kappa \mathrm{B}-\alpha$ 에 결 합되어 통제되지만, LPS 유도로 인해 활성화되어 proteasome 을 통한 ubiquitination을 매개하고, IאB- $\alpha$ 의 분해를 유도하여 조절한다(Cheung 등, 2013). 이어서, NF-אB 복합체는 세포 질에서 핵으로 이동하여 iNOS, COX-2 유도성 효소단백질의 생성 및 염증성 cytokines 생성에 관여하는 유전자의 promoter 에 결합하여 암호화하며, 이들의 생성을 촉진한다(Rehman 등, 2012). 따라서 Raw 264.7 cell에서 염증성 cytokines 발현 에 직접적으로 관여하는 NF- $\mathrm{NB}$ 신호 경로를 조사하기 위하 여 LPS 유도된 Raw 264.7 cell에 $\operatorname{PLE}(20,50,100 \mu \mathrm{g} / \mathrm{mL})$ 를 농도별로 처리하여 NF- $\mathrm{KB}$ complex 중 인산화 된 p65 protein 과 NF- $\mathrm{KB}$ 활성화에 의해 생산된 염증매개물질인 $\mathrm{iNOS}$, COX-2의 발현량을 확인하였다. 그 결과, Fig. 2(A)와 2(B)에 서와 같이 농도별 PLE 처리군에서 cytoplasmic 대비 nuclear 내 p-p65 발현량이 유의하게 감소하였으며, 염증매개물질인 iNOS, COX-2 발현량 측정 결과에서도 p-p65 단백질 발현량 억제 양상과 유사하게 농도에 따라 유의하게 조절하였다. 한 편, $\mathrm{NOS}$ 와 $\mathrm{COX}-2$ 는 주로 염증의 초기 반응에 관여하는데, 이들에 의한 pro-inflammatory mediators인 PTGES2와 nitrite
의 발현량을 측정한 결과, Fig. 2(C)와 2(D)에서와 같이 COX-2 에 의해 매개되어 $\mathrm{PGE}_{2}$ 생성에 관여하는 PTGES2의 mRNA 발현량과 iNOS mediators인 nitrite 발현량이 PLE 처리에 의 해 유의적으로 감소되는 것으로 조사되었다. 이상의 결과에 따라 PLE는 PTGES2와 nitrite를 조절하여 이들의 전사인자 인 iNOS와 COX-2에 대한 직접적인 억제력과 LPS로 유도된 $\mathrm{NF}-\kappa \mathrm{B}$ 신호전달경로의 단계적인 반응을 조절한다고 판단되 었다. 따라서 염증반응에 직접적인 영향을 미치는 인자인 염 증성 cytokine의 발현에도 관여할 것으로 판단되어 이에 대 한 반응을 조사해 보였다.

\section{PLE가 LPS 유도된 Raw 264.7 cell에서 cytokines과 chemokine에 미치는 영향}

$\mathrm{NF}-\kappa \mathrm{B}$ 는 monocytes/macrophages에서 pro-inflammatory cytokines의 유도를 매개한다. 이러한 cytokine의 대부분은 선천성 면역세포 및 섬유아세포에서 NF- $\mathrm{kB}$ 를 활성화하여 추 가적인 염증성 cytokine 및 chemokine의 발현을 유도하여 염 증성 면역세포의 증식과 급성 염증 및 만성 염증의 전염을 유도한다(Vannier, 1992). 염증에 의한 cytokine에는 TNF- $\alpha$,

\section{(A)}

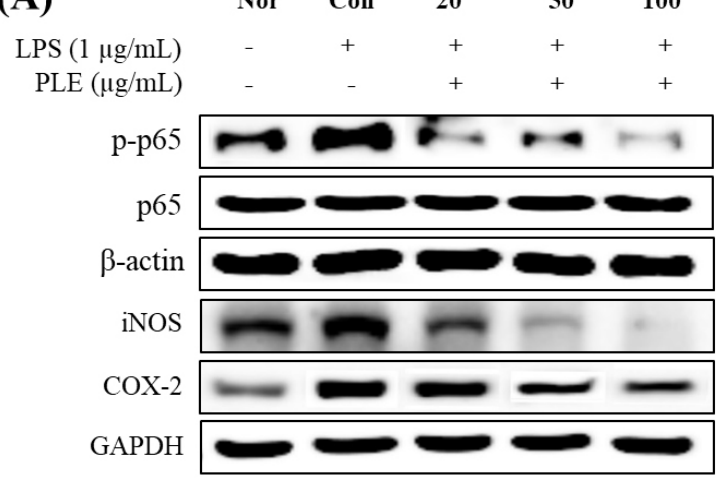

(B)

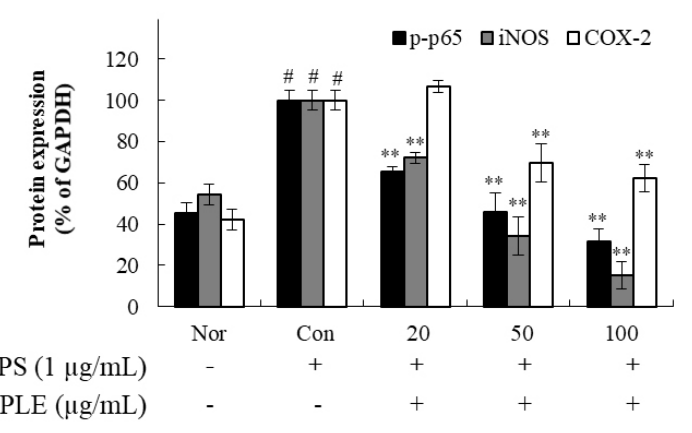

(C)

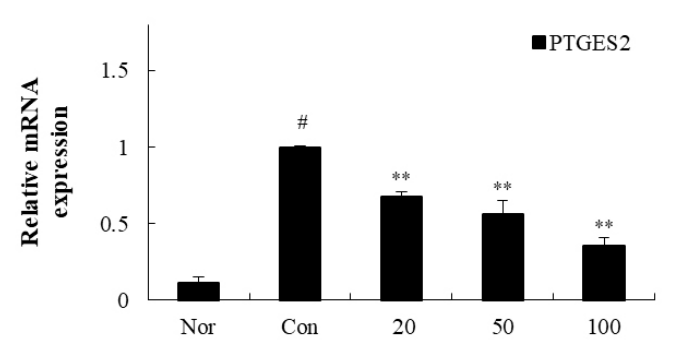

(D)

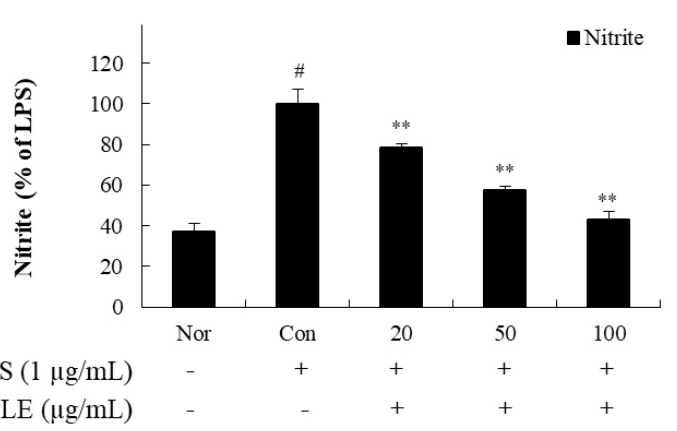

Fig. 2. Effect of PLE on protein expression (A), p-p65, iNOS, and COX-2 expression rate (B), PTGES2 mRNA expression (C), and nitrite production (D) in LPS-induced Raw 264.7 cell with LPS induced.

The values are mean \pm SD of three independent experiments. Nor, LPS not induced group (negative control); Con, only LPS-induced group (positive control). ${ }^{\#} \mathrm{p}<0.01$, compared with LPS not induced group (Nor); ${ }^{* *} \mathrm{p}<0.01$, compared with the only LPS-induced group (Con). 
IL-6, IL-1 $\beta$ 등이 존재하며, 탐식세포를 포함한 면역세포에서 만들어진다. 이들은 모두 국소적으로 작용하여 응고를 유도 하고 혈관투과성을 증가시키며, $\mathrm{COX}-2, \mathrm{iNOS}$ 의 생성을 유 도하는 일들을 수행한다(Bazarsad, 2012). 따라서 NF-kB에 의하여 조절되는 cytokines과 chemokine인 IL- $1 \beta, \mathrm{IL}-6$, TNF$\alpha, \mathrm{MCP}-1$ 에 대해 조사하기 위하여 LPS 유도된 Raw 264.7 cell에 PLE $(20,50,100 \mu \mathrm{g} / \mathrm{mL})$ 를 농도별로 처리하여 IL- $1 \beta$, IL-6, TNF- $\alpha, \mathrm{MCP}-1$ 발현량을 확인하였다. 그 결과, Fig. 3(A) 와 같이 농도별 PLE 처리군에서 L- $1 \beta, \mathrm{IL}-6, \mathrm{TNF}-\alpha, \mathrm{MCP}-1$ 의 mRNA 발현량이 처리 농도가 증가할수록 유의하게 감소 하였다. LPS를 처리하지 않은 Normal(Nor)군과 세포에 LPS 만 처리한 Control(Con)군, LPS 처리 후 농도별 PLE 처리군 의 세포의 형태적인 변화를 관찰한 결과는 Fig. 3(B)와 같다. 처리 후 Nor군에서는 부착성 세포인 macrophage의 형태적 특징인 구형의 모양인 반면, Con군에서는 LPS를 처리함에 따라 노화된 세포의 불규칙적인 모양과 손상된 구조의 뵤족
뾰족하게 뻗은 형태를 나타내었다. LPS 처리 후 농도별 PLE 처리군의 경우, 세포의 형태적인 변화가 Nor군의 상태보다는 손상된 구조와 노화된 세포가 조금 관찰되었지만, 농도별 PLE의 처리에 따라 세포의 부착성과 손상된 구조가 Con군 에 비해 다소 감소하는 것을 확인하여 이는 PLE의 처리 농도 에 따라 형태적 차이를 보인다고 판단하였다. 종합하면, PLE 는 외부의 자극에 의해 손상을 받는 macrophage에 대해 NF$\kappa \mathrm{B}$ 신호 경로와 cytokine의 발현량을 감소시키는 것을 확인 하였으며, 따라서 PLE가 염증반응에 관여하는 인자들을 하 향 조절하는 것으로 판단할 수 있었다. 따라서 본 연구에서는 PLE가 염증반응을 저해하는 기능성 식품 소재 및 항염증 치 료제로서의 가능성과 가치를 확인하였으며, 염증 억제에 대 한 잠재력 뿐만 아니라, 국내에 자생하는 우수 생물자원에 대 한 적극적인 발굴 연구 및 유용 생물자원의 활용성 증대를 위한 기술 개발 산업에서 유익한 응용 가능성을 제시하는 연 구임을 시사하는 바이다.

(A)

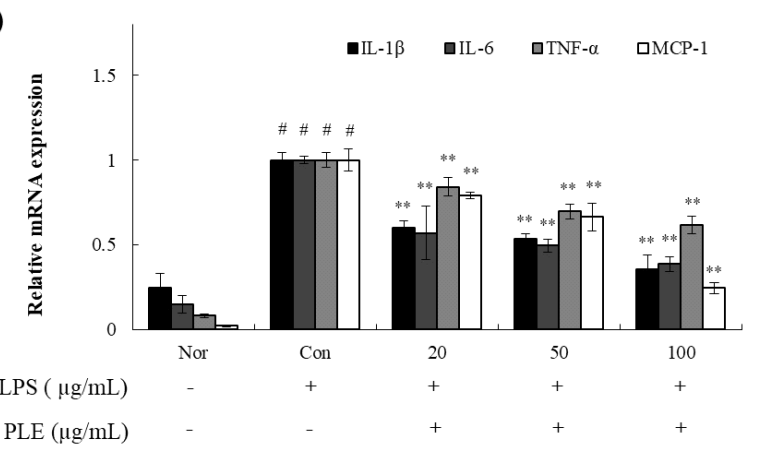

(B)

$\operatorname{PLE}(\mu \mathrm{g} / \mathrm{mL})$

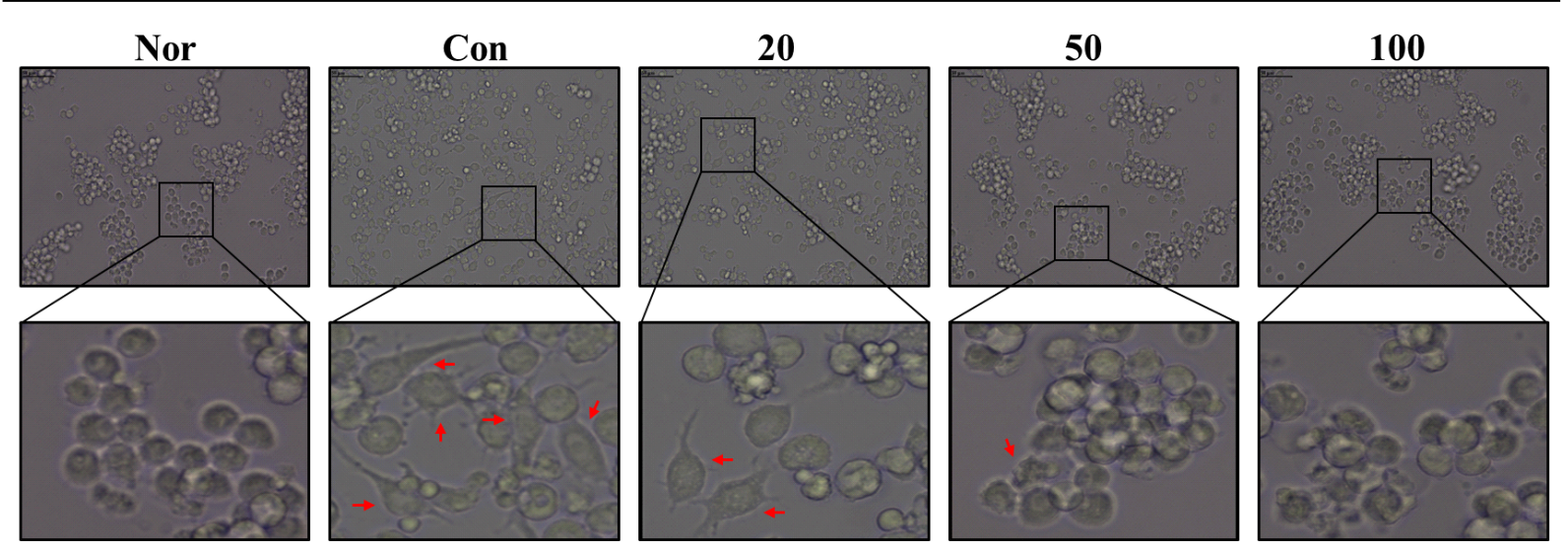

Fig. 3. Effect of PLE on IL-1ß, IL-6, TNF- $\alpha$, and MCP-1 mRNA expression (A), and cell morphological changes (B) in LPS-induced Raw 264.7 cell with LPS-induced.

Cell morphological changes were monitored by inverted phase-contrast microscopy (magnification, $\times 400$ ). The values are mean \pm SD of three independent experiments. Nor, LPS not induced group (negative control); Con, only LPS-induced group (positive control). ${ }^{\#}$ p $<0.01$, compared with LPS not induced group (Nor); ${ }^{* *} \mathrm{p}<0.01$, compared with the only LPS-induced group (Con). 


\section{요 약}

본 연구에서는 한국, 일본, 중국 남부, 타이완 및 인도차이 나의 따뜻한 지역에서 자라며, 생약 자원으로 이용되고 있는 석위(Pyrrosia lingua) 잎을 사용하여 국내 유용작물로 개발 가능성을 확인하고자 하였다. 면역세포인 macrophage를 사 용하여 PLE의 염증 억제에 미치는 영향을 확인하였다. 따라 서 석위가 염증과 관련된 macrophage에서 발현되는 인자들 에 미치는 영향을 측정하기 위하여 Raw 264.7 cell에 PLE가 가지는 세포에 대한 독성 측정, 시간 변화에 따른 세포의 수 측정, 형태학적 변화를 관찰하였다. 그리고 Raw 264.7 cell에 서 NF-kB 신호전달 조절을 통해 cytokine의 발현량을 조절 하기 위해 시료를 처리하여 NF-kB p-65, iNOS, COX-2 단백 질을 확인한 후 이들의 pro-inflammatory mediators인 PTGES2 와 nitrite의 발현량, cytokines, chemokine 발현 수준을 통해 염증 억제 연구를 수행하였다. PLE의 Raw 264.7 cell에 대한 세포독성과 시간별 세포 수의 변화, 형태적인 변화를 확인한 결과, PLE에서는 처리한 농도에 구별없이 유의한 결과가 나 타나지 않았다. PLE의 Raw 264.7 cell에서 NF-kB 신호전달 조절에 관여하는 단백질의 발현에 미치는 영향을 조사한 결 과, PLE의 처리 농도에 따라 NF-kB p-65, iNOS, COX-2 단 백질의 발현을 강하게 억제할 뿐만 아니라, iNOS, COX-2의 pro-inflammatory mediators인 PTGES2와 nitrite에서도 PLE 처리에 의해 발현량이 하향 조절되는 것을 확인하였다. 또한 PLE의 NF- $\kappa \mathrm{B}$ 신호전달 조절을 통해 pro-inflammatory cytokines과 chemokine의 발현량을 측정한 결과 IL-1 $\beta$, IL-6, TNF- $\alpha$, MCP- 1 발현량에 PLE가 유의하게 관여한다는 것을 규명하였다. 위의 결과로부터 PLE가 NF-kB 신호전달 조절 과 cytokine 억제 효과를 가지고 있어 국내 생물자원의 활용 성 증대와 이를 활용한 기능성 신소재로 매우 유용하게 활용 될 수 있을 것으로 판단되었다.

\section{Conflict of interests}

The authors declare no potential conflict of interest.

\section{ORCID}

Shin Hyub Hong https://orcid.org/0000-0001-7455-0660 Eun-Ho Lee https://orcid.org/0000-0002-5759-639X Young-Je Cho https://orcid.org/0000-0002-2365-6294

\section{References}

Barroso M, Kao D, Blom HJ, Tavares de Almeida I, Castro
R, Loscalzo J, Handy DE. S-Adenosylhomocysteine induces inflammation through NFkB: A possible role for EZH2 in endothelial cell activation. Biochimica et Biophysica Acta, 1862, 82-92 (2016)

Bazarsad D. Effect of Glycyrrhiza uralensis F. extracts and its fermented products on inflammatory cytokine expression in $\mathrm{HaCaT}$ cells. MS Thesis, Chungbuk National University, Korea (2012)

Bishop-Bailey D, Calatayud S, Warner TD, Hla T, Mitchell JA. Prostaglandins and the regulation of tumor growth. J Environ Pathol Toxicol Oncol, 21, 93-101 (2002)

Chen L, Ma YJ, Li YP, Zhang Y, He F, Chen YG. Advance on the chemical and pharmacological studies on plants of Pyrrosia genus. J Anhui Agric Sci, 39, 3 (2011)

Cheung DW, Koon CM, Wat E, Ko CH, Chan JY, Yew DT, Leung PC, Chan WY, Lau CB, Fung KP. A herbal formula containing roots of Salvia miltiorrhiza (Danshen) and Pueraria lobata (Gegen) inhibits inflammatory mediators in LPS-stimulated RAW 264.7 macrophages through inhibition of nuclear factor kappaB (NFkappaB) pathway. J Ethnopharmacol, 145, 776-783 (2013)

Do JC, Jung KY, Son KH. Flavonoid glycosides from the fronds of Pyrrosia lingua. Kor J Pharmacogn, 23, 276-279 (1992)

Gordon DR. Effects of invasive, Non-indigenous plant species on ecosystem processes: Lessons from Florida. Ecological Application, 8, 975-989 (1998)

Harris SG, Padilla J, Koumas L, Ray D, Phipps RP. Prostaglandins as modulators of immunity. Trends Immunol, 23, 144-150 (2002)

Ji JD, Lee YH, Song GG. Prostaglandin $\mathrm{E}_{2}\left(\mathrm{PGE}_{2}\right)$ : Roles in immune responses and inflammation. $\mathrm{J}$ Korean Rheum Assoc, 11, 307-316 (2004)

Kim BS, Lee BJ, Lee HJ, An SY, Park ZW, Yoon SH, Oh MJ, Kwon J, Lee SY, Cha DS, Oh $\mathrm{CH}$, Jeon $\mathrm{H}$. Protective effects of pyrrosiae folium on the $2 \%$ glucoseinduced toxicity in caenorhabditis elegans. Kor $\mathrm{J}$ Pharmacogn, 48, 179-186 (2017)

Kim HJ, Kim KW, Yu BP, Chung HY. The effect of age on cyclooxygenase-2 gene expression: NF-кB activation and IKB degradation. Free Radical Biol Med, 28, 683692 (2000)

Kim HL, Yang SH, Oh YK, Lee JE, Oh JE, Yoon HJ, Kim YS, Ahn C, Han JS, Kim SG, Lee JS. The effects of polymorphism in the MCP-1 gene regulatory region on 
MCP-1 expression and the manifestation of lupus nephritis. Korean J Nephrol, 21, 137-144 (2002)

Kim M, Park J, Lim S. Antioxidant activity and cell toxicity of pressurised liquid extracts from 20 selected plant species in Jeju. Korea Food Chem, 122, 546-552 (2010)

Kuo $\mathrm{YH}$, Chen $\mathrm{CW}$, Chu $\mathrm{Y}$, Lin $\mathrm{P}$, Chiang HM. In vitro and in vivo studies on protective action of $N$-phenethyl caffeamide against photodamage of skin. PLoS ONE, 10, 1-13 (2015)

Lee SY, Shin YJ, Park JH, Kim SM, Park CS. An analysis of the gyungokgo's ingredients and a comparison study on anti-oxidation effects according to the kinds of extract. Kor J Herbology, 23, 123-136 (2008)

Lim HJ, Kwon J, Jeon H. Pyrrosia lingua reduces nociception in mouse. Kor J Pharmacogn, 20, 285-289 (2014)

Lindstrom TM, Bennett PR. The role of nuclear factor kappa B in human labour. Reproduction, 130, 569-581 (2005)

Mases M. The cytokine hypothesis of depression: inflammation, oxidative \& nitrosative stress (IO\&NS) and leaky gut as targets for adjunative treatment in depression. Neuro Endocrinol Lett, 29, 287-291 (2008)

Oh YC, Cho WK, Jeong YH, Im GY, Lee KJ, Yang HJ, Ma JY. Anti-inflammatory effect of Sosihotang via inhibition of nuclear factor-kappaB and mitogen-activated protein kinases signaling pathways in lipopolysaccharidestimulated RAW 264.7 macrophage cells. Food Chem
Toxicol, 53, 343-351 (2013)

Park MH, Hong JT. Roles of NF- $\mathrm{B}$ in cancer and inflammatory diseases and their therapeutic approaches. Cells, 5, 15 (2016)

Rehman MU, Yoshihisa Y, Miyamoto Y, Shimizu T. The anti-inflammatory effects of platinum nanoparticles on the lipopolysaccharide-induced inflammatory response in RAW 264.7 macrophages. Inflamm Res, 61, 1177-1185 (2012)

Ryu JH, Ahn H, Kin JY, Kim YK. Inhibitory activity of plant extracts on nitrix oxide synthesis in LPS-activated macropage. Phytother Res, 17, $485-489$ (2003)

Shin JS, Park SJ, Ryu S, Kang HB, Kim TW, Choi JH, Lee JY. Cho YW, Lee KT. Potent anti-inflammatory effect of a novel furan-2,5-dione derivative, BPD, mediated by dual suppression of COX-2 activity and LPS-induced inflammatory gene expression via NF-kappaB inactivation. Br J Pharmacol, 165, 1926-1940 (2012)

Vannier E, Miller LC, Dinarello CA. Coordinated antiinflammatory effects of interleukin 4: Interleukin 4 suppresses interleukin 1 production but up-regulates gene expression and synthesis of interleukin 1 receptor antagonist. Proc Natl Acad Sci USA, 89, 4076-4080 (1992)

Yamashita H, Masuda K, Kobayashi T, Ageta H, Shiojima K. Dammarane triterpenoids from rhizomes of Pyrrosia lingua. Phytochemistry, 49, 2461-2466 (1998) 